\title{
Clinico Pathological Correlation of Chronic Obstructive Pulmonary Disease among Rural Population of North India
}

\author{
Adesh Kumar ${ }^{1}$, Mani Krishna², Seema Dayal2 ${ }^{*}$
}

\begin{abstract}
Affiliations:
'Department of Pulmonary Medicine, Rural Institute of Medical Science \& Research, Saifai, Etawah (U.P.), India

2Department of Pathology, Rural Institute of Medical Science \& Research, Saifai, Etawah (U.P.), India
\end{abstract}

Correspondence to:

Dr. Seema Dayal

Associate Professor

Department of Pathology

Rural Institute of Medical Science \& Research

Saifai, Etawah (U.P.), India

Email: seemadayal77@rediffmail.com

How to cite this article:

Kumar A, Krishna M, Dayal S. Clinico Pathological Correlation of Chronic Obstructive Pulmonary Disease among Rural Population of North India. Ann. Clin. Chem. Lab. Med. 2016:2(1);7-10

DOI: http://dx.doi.org/10.3126/acclm.v2i1.14578

(C) 2016 Nepalese Association for Clinical Chemistry

\section{(c) (1) (2)}

This work is licensed under a Creative Commons Attribution-ShareAlike 4.0 International License.
Abstract

\section{BACKGROUND}

Chronic obstructive pulmonary disease (COPD) is a major cause of chronic morbidity and mortality in rural population. COPD is characterized by chronic airflow limitation and a range of pathological changes in the lung, some significant extra-pulmonary effects, and important co morbidities which may contribute to the severity of the disease in individual patients.

\section{METHODS}

This study was conducted in Department of Pulmonary Medicine and central laboratory from $1^{\text {st }}$ January 2015 to $31^{\text {st }}$ December 2015 in Rural Institute of Medical Science \& Research, Saifai, Etawah (U.P.), India on patients who presented with symptoms of COPD.

\section{RESULTS}

The age group of the patient in the study, ranged from 35 to 85 years. The most common age group was $61-70$ years $(32.99 \%)$. Among these patients $92.95 \%$ were males and $7.04 \%$ were females. Dyspnoea $(84.50 \%)$ was the common clinical manifestation. Out of 497 patients, $94.96 \%$ were smokers and $5.03 \%$ were non-smokers. Among these COPD patients $25.15 \%$ males and $4.82 \%$ females had normal hemoglobin. Similarly, normal total leukocyte count, differential leukocyte count was seen in $56.13 \%$ males and $3.82 \%$ females. The gram negative isolates were $63.32 \%$ as compared to $36.82 \%$ of gram positive. On sputum cytology, bacteria were found in $64.18 \%$ and fungus in $35.81 \%$. During sputum culture, Streptococcus $(29.97 \%)$, was the commonest bacteria isolated followed by Moraxella (25.55\%) and Pseudomonas (16.90\%). Fungal isolates were Aspergillus (27.96\%) and Candida spp. (7.84\%).

\section{CONCLUSIONS}

COPD was common in older age group, males, and smokers. Patients predominantly presented with dyspnea and chronic cough. Streptococcus was the most common organism isolated and fungus species were also isolated.

KEYWORDS: Chronic Obstructive Pulmonary disease (COPD), Hematology, Sputum cytology, Culture 


\section{Introduction}

Chronic Obstructive Pulmonary Disease (COPD) is a lung disease defined by persistently poor airflow as a result of breakdown of lung tissue (known as emphysema) and dysfunction of the small airways [1]. It typically worsens over time. COPD is a major cause of chronic morbidity and mortality and represents a substantial economic and social burden throughout the world. According to World Health Organization, COPD was fourth cause of death in the developed countries and fifth in the world [2].

Tobacco smoking is by far the major risk factor for COPD [3], and the prevalence of the disease in different countries is related to rates of smoking and time of introduction of cigarette smoking. It constitutes $30 \%$ of patients in chest clinics and accounts for 1 to $2.5 \%$ of admission in hospital all over India. It is both a rural and urban health problem, the prevalence varying from $1 \%$ in urban non-smoker to $21 \%$ in rural smoker [4]. COPD develops over time and usually manifest in people over 45 years of age. Severe deficiency for alpha-1-antitrypsin is rare and the impact of other genetic factors on the prevalence of COPD has not been established. COPD should be considered in any patient presenting with cough, sputum production, or dyspnoea, especially if an exposure to risk factors for the disease has been present. Clinical diagnosis needs to be confirmed by spirometric tests in the presence of not-fully-reversible airflow limitation. Laboratory diagnosis is must to diagnose COPD along with clinical history, physical examination and pulmonary function tests. So this study was planned to know clinical characters, hematology, sputum cytology, Microbial flora and their correlation with COPD patients.

\section{Methods}

This study was conducted in Department of Pulmonary Medicine and central laboratory from 1 January 2015 to 31 December 2015 in Rural Institute of Medical Science \& Research, Saifai, Etawah (U.P.), India on patients who presented with symptoms of COPD. Detailed clinical history and associated clinical findings were taken in pre designed proforma. Hematology investigations such as Hemoglobin, MCV, $\mathrm{MCH}, \mathrm{MCHC}$, Total leucocyte count (TLC), Differential Leucocyte count (DLC), Erythrocyte sedimentation rate was done in all patients. Giemsa stained slide preparations was also done to make peripheral smears. For Sputum examination direct smears were prepared and stained with $\mathrm{H} \& \mathrm{E}$ and Giemsa stain. Gram stain was done on the smears for the morphological identification of organism. It is also applied to identify gram positive and Gram negative bacteria. Sputum culture was also done to isolate microorganism using MacConkey's agar, chocolate agar, Sabouraud agar.

\section{Results}

In this study, we included 497 patients who presented with COPD during the period. The age group of the patient in the study, ranged from 35 to 85 years. The most common age group was $61-70$ years (32.99\%). The next common age group was $51-60$ years $(29.97 \%)$ [Table 1]. Among these patients $92.95 \%$ were males and $7.04 \%$ were females. [Table 2]. Dyspnoea $(84.50 \%)$ was the common clinical manifestations in the patients. Majority of the patients had chronic cough $(81.48 \%)$. Out of them $87.12 \%$ were smokers and $12.87 \%$ were non-smokers [Table 3].

Table 1. Age distribution of patients with COPD.

\begin{tabular}{lcc}
\hline Age in years & Number & Percentage \\
\hline 31-40 years & 35 & $7.04 \%$ \\
41-50 years & 109 & $21.93 \%$ \\
51-60 years & 149 & $29.97 \%$ \\
$\mathbf{6 1 - 7 0}$ years & 164 & $32.99 \%$ \\
$\mathbf{7 1 - 8 0}$ years & 35 & $7.04 \%$ \\
$\mathbf{8 1 - 9 0}$ years & 5 & $1.00 \%$ \\
Total & 497 & \\
\hline
\end{tabular}

Table 2. Smoking status among the gender of COPD patients

\begin{tabular}{lccc}
\hline & Smokers & Non-smokers & Total \\
& $\mathrm{N}(\%)$ & $\mathrm{N}(\%)$ & \\
\hline Male & $446(89.7 \%)$ & $16(3.2 \%)$ & $462(92.9 \%)$ \\
Female & $26(5.2 \%)$ & $9(1.8 \%)$ & $35(7.0 \%)$ \\
Total & $472(94.9 \%)$ & $25(5.0 \%)$ & 497 \\
\hline
\end{tabular}

Among the COPD patients $25.15 \%$ males had normal hemoglobin values and $4.82 \%$ females had normal hemoglobin values. Normal TLC values were seen in $56.13 \%$ males and $3.82 \%$ females.

On sputum cytology, bacteria were found in $64.18 \%$ and fungus in $35.81 \%$. The prevalence of Gram negative isolates was $63.32 \%$, as compared to $36.82 \%$ of gram positive. 
Table 3. Clinical symptoms among COPD patients

\begin{tabular}{lcc}
\hline Clinical symptoms & Number & Percentage \\
\hline Dyspnea & 420 & $84.50 \%$ \\
Chronic cough & 405 & $81.48 \%$ \\
Wt. loss & 244 & $49.09 \%$ \\
Pneumo thorax & 105 & $21.32 \%$ \\
Anemia & 85 & $17.10 \%$ \\
Others & 53 & $10.66 \%$ \\
\hline
\end{tabular}

Table 4. Microorganisms isolated in COPD patients

\begin{tabular}{lcc}
$\begin{array}{l}\text { Microorganism } \\
\text { isolated }\end{array}$ & Number & Percentage \\
\hline Streptococcus & 149 & $29.97 \%$ \\
Moraxella & 127 & $25.55 \%$ \\
Pseudomonas & 84 & $16.90 \%$ \\
Klebsiella & 69 & $13.88 \%$ \\
E. coli & 44 & $8.85 \%$ \\
Staphylococcus & 34 & $6.84 \%$ \\
Micrococcus & 9 & $1.81 \%$ \\
Aspergillus & 139 & $27.96 \%$ \\
Candida spp. & 39 & $7.84 \%$ \\
\hline
\end{tabular}

During culture Streptococcus (29.97\%) was the commonest bacteria isolated followed by Moraxella (25.55\%), Pseudomonas (16.90\%), Klebsiella (13.88\%), E. coli (8.85\%), Staphylococcus aureus $(6.84 \%)$ and Micrococcus spp. (1.81\%) [Table 4]. Out of total bacterial infection, $58.95 \%$ samples had single microbial infections and $12.8 \%$ had polymicrobial infections.

Among microbial growth, $62.9 \%$ were Gramnegative bacteria and $36.8 \%$ were Gram-positive bacteria. The pattern of polymicrobial infection was as follows. Streptococcus with Moraxella, Escherichia coli, Pseudomonas, Klebsiella; and Staphylococcus with Klebsiella. Fungal infection was found in 178 sputum samples with $27.96 \%$ Aspergillus and $7.84 \%$ Candida species [Table 4].

\section{Discussion}

COPD is a lung disease defined by persistently poor airflow as a result of breakdown of lung tissue (known as emphysema) and dysfunction of the small airways [5]. It typically worsens over time. Severe COPD is a common problem in patients hospitalized on respiratory medicine ward. The burden of disease is great both for those directly affected and for society. In present study, we observed that age of patients ranged from 35 to 85 years. However, 61-70 year constituted maximum no. of cases $(32.99 \%)$ [Table 1]. Thus, COPD was common in older age group. This is because it was more commonly seen in patients with advanced lung disease as an expression of deterioration in host defenses at the bronchial mucosal level.

COPD was more common in males $(92.95 \%)$ in comparison to females (7.04\%). The male preponderance was seen in our study because most of them were smokers and in our study COPD was more common among smokers $(94.96 \%)$ than in non-smokers $(5.03 \%)$ [Table 2], which was similar to other studies [6]. In non-smokers, especially among women, exposure to indoor air pollution was an important factor [7].

A clinical diagnosis of COPD should be considered in any patient who has dyspnea, chronic cough or sputum production but severe cases are complicated by weight loss, pneumothorax, respiratory failure and a history of exposure to risk factors for the disease $[8,9]$. In our study, common clinical symptom was Dyspnea $(84.50 \%)$ followed by chronic cough $(81.48 \%)$ and others [Table 3].

Hematological investigation especially hemoglobin examination is required to rule out anemia and polycythemia, though $\mathrm{MCV}, \mathrm{MCH}$ and $\mathrm{MCHC}$ are done to know the type of anemia [10]. In present study, normal level of hemoglobin was seen in $25.15 \%$ males and in $4.82 \%$ females [Table 4]. Normal value of TLC and DLC was seen in $56.13 \%$ males and 3.82\% females while other showed leukocytosis which might be due to chronic pathology. Normal ESR level was seen in $26.55 \%$ males and $4.02 \%$ females while other showed raised level which occurs due to inflammatory pathology. MCV, $\mathrm{MCH}$ and $\mathrm{MCHC}$ normal levels were found in $25.55 \%$ males and $4.82 \%$ females where raised $\mathrm{MCV}, \mathrm{MCH}$ are associated with polycythemia and reduced level are associated with anemia.

The role of bacteria in exacerbations of COPD remains controversial, since bacterial species are present in the airways of between $25-50 \%$ of patients with COPD even when in a stable condition. Bacteria play either a primary role in the development of exacerbations of COPD or represent a secondary infection following an initial viral process and followed by fungal infection. Our country has a wide climatic variation and COPD is more common in northern India because of long cold winter.

Sputum analysis after sputum induction gives useful information about airways inflammation in COPD [11]. It is also useful in serial 
monitoring of induced sputum inflammatory markers in COPD. It can also be used to investigate different aspects of airways inflammation. Sputum cytology has given evidence for increased number of marcophages, polymorph and eosinophils in COPD [12]. In present study, bacteria were found in $64.18 \%$ and fungus in $35.81 \%$ of patients with COPD [Table 4]. Gram's stain also gives information regarding epithelial cells and inflammatory cells. In present study, inflammatory cells and epithelial cells were found in all gram stained smears. The prevalence of Gram negative isolates was $63.32 \%$, as compared to $36.82 \%$ of gram positive. The Gram negative organisms were more common in the patients with the most severe lung dysfunction, whereas the Gram negative bacteria predominated in the exacerbations of the patients with the mildest degree of lung function abnormalities. Among the isolates, Streptococcus was the commonest bacteria isolated in $29.97 \%$, followed by Moraxella isolated in $25.55 \%$ cases. Fungi also play important role in the exacerbation of COPD. Fungal species were identified in the induced sputum samples, Aspergillus $27.96 \%$ and Candida $7.84 \%$ are identified [Table 4].

\section{Conclusion}

COPD was common in older age group, males, and smokers. Patients predominantly presented with dyspnea and chronic cough. Streptococcus was the most common organism isolated and fungus species were also isolated.

\section{Conflict of Interest}

None declared

\section{REFERENCES}

1. Anto JM and Vermeire P. Epidemiology of Chronic Obstructive Pulmonary Disease. Eur Respir J. 2001;17:982-93. http://dx.doi.org/10.1183/0903193 6.01 .17509820

2. The top 10 causes of death. World Health Organization fact sheet (Updated May 2014). Available at: http://who.int/mediacentre/factshee ts/fs310/en/. Accessed August 2014

3. Vestibo J, Jorgen P. Global strategy for the diagnosis, management and prevention of Chronic Obstructive Pulmonary Disease. Global initative for Chronic Obstructive Lung Disease. Am J Respir Crit Care Med. 2013;187:347 -365.

http://dx.doi.org/10.1164/rccm.201 204-0596PP

4. Arora N, Daga MK. Microbial pattern of Acute infective exacerbation of Chronic Obstructive Airway Disease in a hospital based study. Indian Chest Dis. 2001;41:65-7.

5. Decramer M, Janssens W,
Miravitlies M. Chronic Obstructive Pulmonary Disease. Lancet. 2012; 379(9823):1341-51.

http://dx.doi.org/10.1016/S01406736(11)60968-9

6. Jindal SK, Agarwal AN, Gupta D. A review of population studies from India to estimate national burden of Chronic Obstructive Pulmonary Disease and its association with smoking. Indian J Chest Dis. 2001;43:139-147.

7. Kennedy SM, Chambers R, Du W, Ward DH. Environmental and occupational exposures. Proc Am Thorac Soc. 2007;4(8):692-4. http://dx.doi.org/10.1513/pats.200 707-094SD

8. Philip G, Swadron S. The acute presentation of Chronic Obstructive Pulmonary Disease in emergency department: A Challenging Oxymoron [Internet] Emergency Medicine Practice; 2008 [cited 2016 Feb 21]. Available from https://goo.gl/Yu8V3p

9. Mahler DA. Mechanisms and measurement of dyspnea in Chronic Obstructive Pulmonary Disease. Proc Am Thorac Soc. 2006;3(3):234-8.

http://dx.doi.org/10.1513/pats.200 509-103SF

10. Chaturvedi U, Singh T. Practical Pathology. $2^{\text {nd }}$ ed. New Delhi: Arya Publications; 2007

11. Pizzichini E, Pizzichini MM, Gibson P. Sputum eosinophilia predicts benefits from prednisone in smokers with Chronic Obstructive Pulmonary Disease. Am J Respir Cit Med 1998;158:1511-17.

http://dx.doi.org/10.1164/ajrccm.1 58.5.9804028

12. Gupta K B, Garg S. Sputum induction -A useful tool in diagnosis of respiratory diseases. Lung India 2006;23:82-6.

http://dx.doi.org/10.4103/09702113.44416

13. Ananthanarayan R, Paniker J. Text Book of Microbiology. $6^{\text {th }}$ ed. Hyderabad (India): Orient Longman Pvt. Ltd.; 2002 